\title{
Binding of extracellular matrix proteins to Paracoccidioides brasiliensis
}

\author{
Maria José Soares Mendes-Giannini ${ }^{\text {a,* }}$, Patrícia Ferrari Andreotti ${ }^{\text {a }}$, Luciana Raquel Vincenzi ${ }^{\text {a }}$, \\ Juliana Leal Monteiro da Silva ${ }^{\mathrm{a}}$, Henrique Leonel Lenzi ${ }^{\mathrm{b}}$, Gil Benard ${ }^{\mathrm{c}}$, \\ Roseli Zancopé-Oliveira ${ }^{\mathrm{d}}$, Herbert Leonel de Matos Guedes ${ }^{\mathrm{d}}$, \\ Christiane Pienna Soares ${ }^{\text {a }}$ \\ a Departamento de Análises Clínicas, Faculdade de Ciências Farmacêuticas, UNESP, R. Expedicionários do Brasil, 1621, \\ 14802-901 Araraquara São Paulo, Brazil \\ ${ }^{\mathrm{b}}$ Departamento de Patologia, Instituto Oswaldo Cruz-Fiocruz, Rio de Janeiro, RJ, Brazil \\ ${ }^{\mathrm{c}}$ Laboratório de Alergia e Imunologia Clínica e Experimental and Clínica de Doenças Infecciosas e Parasitárias, Faculdade de Medicina, \\ USP, São Paulo, Brazil

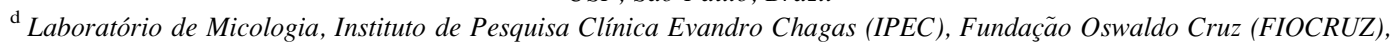 \\ Rio de Janeiro, RJ, Brazil
}

Received 30 June 2005; accepted 16 January 2006

Available online 7 April 2006

\begin{abstract}
Adhesion to extracellular matrix (ECM) proteins plays a crucial role in invasive fungal diseases. ECM proteins bind to the surface of Paracoccidioides brasiliensis yeast cells in distinct qualitative patterns. Extracts from Pb18 strain, before (18a) and after animal inoculation (18b), exhibited differential adhesion to ECM components. Pb18b extract had a higher capacity for binding to ECM components than Pb18a. Laminin was the most adherent component for both samples, followed by type I collagen, fibronectin, and type IV collagen for $\mathrm{Pb} 18 \mathrm{~b}$. A remarkable difference was seen in the interaction of the two extracts with fibronectin and their fragments. Pb18b extract interacted significantly with the $120-\mathrm{kDa}$ fragment. Ligand affinity binding assays showed that type I collagen recognized two components (47 and $80 \mathrm{kDa}$ ) and gp43 bound both fibronectin and laminin. The peptide 1 (NLGRDAKRHL) from gp43, with several positively charged amino acids, contributed most to the adhesion of $P$. brasiliensis to Vero cells. Synthetic peptides derived from peptide YIGRS of laminin or from RGD of both laminin and fibronectin showed the greatest inhibition of adhesion of gp43 to Vero cells. In conclusion, this work provided new molecular details on the interaction between $P$. brasiliensis and ECM components.
\end{abstract}

(C) 2006 Elsevier SAS. All rights reserved.

Keywords: Paracoccidioides brasiliensis; Extracellular matrix; Adhesins; gp43

\section{Introduction}

Paracoccidioides brasiliensis is a dimorphic fungus that causes systemic disease in humans. In paracoccidioidomycosis, clinical and experimental data have indicated the lung as the organ of entry of $P$. brasiliensis, through the inhalation of its conidia and its transformation into the pathogenic yeast form [1].

\footnotetext{
* Corresponding author. Tel.: +55 (16) 33016556; fax: +55 (16) 33016547.

E-mail address: giannini@fcfar.unesp.br (M.J.S. Mendes-Giannini).
}

The spectrum of paracoccidioidomycosis ranges from benign and localized to severe and disseminated forms. The existence of different clinical forms of this disease and the occurrence of asymptomatic infection may be a result of host-related factors, immunological status and characteristics of the infecting agent, mainly its virulence [1]. The propagules that lodge in the alveoli adhere and invade the alveolar cells and/or the basal lamina. Alveolar basal lamina is composed of a specialized extracellular matrix (ECM), in which laminin, types IV and V collagen, entactin, proteoglycans of chondroitin sulfate and heparan sulfate, and fibronectin can be found [2]. In normal tissues, most ECMs are covered by epithelial 
or endothelial cells and hence are not available for binding. However, any type of trauma that damages host tissues may expose the ECM and enable microbial colonization and infection [3].

$P$. brasiliensis may actively penetrate the mucocutaneous surface and parasitize epithelial cells, thus evading the host defenses and reaching deeper tissues [4]. The ability of this fungus to adhere to and invade non-professional phagocyte cells has been reported by us [4]. It has also been demonstrated that a $\mathrm{Pb}$ isolate invaded HeLa and Vero cells, that the adherence phenomenon varies among strains and correlates with their virulence [5]. The virulence of $P$. brasiliensis can be attenuated or even lost after consecutive cycles of subculturing over long periods and can be reestablished after passage in animals and epithelial cell culture [6]. However, the putative factor involved in the virulence of these strains has not yet been identified. Some researchers have analyzed the 43-kDa glycoprotein that is also involved in $P$. brasiliensis, adhesion [5,7], but the other fungal components, such as the 19-, 30-, 32-kDa proteins, as well as glyceraldehyde-3-phosphate dehydrogenase $(\mathrm{GAPDH})$ participate in the adhesion process [4,8-10].

The ability of a microorganism to adhere and invade is recognized as an important factor of its pathogenicity [3]. Adherence implies that the fungus recognizes ligands on the surface of host cells or a constituent of ECM. Nevertheless, adhesion is only one factor among many that can promote the development of this infectious process. The mechanism of adherence has been studied extensively in pathogenic bacteria and fungi such as Candida albicans, Aspergillus fumigatus, Sporothrix schenckii, Coccidioides immitis, Histoplasma capsulatum and Penicillium marneffei [11-16], but little is known about the adherence mechanism in $P$. brasiliensis.

The aim of the present study was thus to further characterize the interaction of $P$. brasiliensis with ECM components (fibronectin, laminin and types I and IV collagen), using fluorescence microscopy, adherence tests and ligand affinity blotting, as well as to define the functional sites of gp43.

\section{Materials and methods}

\subsection{Microorganism}

Strain 18 of $P$. brasiliensis (Pb18) was isolated from a clinical case of paracoccidioidomycosis (PCM) and maintained in the Faculty of Medicine of the University of Sao Paulo (FM-USP), Brazil. During the current work, Pb18 was grown in PYG medium (peptone, yeast extract and glucose) at $35{ }^{\circ} \mathrm{C}$ and subcultured every 3-4 days, 72 times, to yield sample $\mathrm{Pb} 18 \mathrm{a}$.

\subsection{Reisolation of $\mathrm{P}$. brasiliensis}

Pb18 was inoculated into male hamster testicles, using $0.2 \mathrm{ml}$ of a standard suspension of $2.0 \times 10^{6}$ yeasts $/ \mathrm{ml}$ per animal. After 30 days, the animals were sacrificed and the testicles macerated and cultured on Sabouraud agar with chloramphenicol at $25{ }^{\circ} \mathrm{C}$ until the development of characteristic
$P$. brasiliensis mycelial colonies. These were identified and incubated at $35^{\circ} \mathrm{C}$ in PYG medium, to obtain the yeast phase [17], and the resulting sample was labeled Pb18b.

\subsection{Cell-free fungal extract and gp43}

Cell-free fungal extracts were prepared from the 18a and $\mathrm{b}$ isolates in yeast form, as described elsewhere [18]. About $300 \mathrm{mg}$ of $P$. brasiliensis cells was grown for 3-4 days on PYG solid medium, then scraped off and mixed with $1 \mathrm{ml}$ of PBS, pH 7.2. This mixture was vortexed for $30 \mathrm{~s}$ and centrifuged at $560 \times g$ for $1 \mathrm{~min}$. The supernatant (cell-free fungal extract) was removed and stored at $-20{ }^{\circ} \mathrm{C}$. The gp43 was purified from crude exoantigen of $P$. brasiliensis (strain 18) as previously described [19]. Briefly, the exoantigen was fractionated by affinity chromatography in columns of protein A-purified rabbit anti-gp43 IgG coupled to CNBr-Sepharose. The gp43 fraction was concentrated and further purified by gel filtration. Analysis by sodium dodecyl sulfate-polyacrylamide gel electrophoresis (SDS-PAGE) and silver staining showed a single band with a molecular weight of $43 \mathrm{kDa}$. The cell-free fungal extracts of $P$. brasiliensis (strains 18a and b) were also biotin-labeled by incubation with sulfo-NHS-biotin (ECL protein biotinylation module from Amersham Pharmacia Biotech ${ }^{\circledR}$ ) following the manufacturer's instructions (the stock solution of labeled protein was $1 \mathrm{mg} / \mathrm{ml}$ ).

\subsection{P. brasiliensis antisera}

Polyclonal antisera to $P$. brasiliensis cell-free fungal extract (Pb18b) and gp43 fraction were generated by immunizing rabbits with intradermal injections of $1.0 \mathrm{ml}$ of protein (respectively, 1.2 and $1.0 \mathrm{mg} / \mathrm{ml}$ ) mixed with $1.0 \mathrm{ml}$ of Freund's complete adjuvant. Subsequent injections of protein with incomplete adjuvant were given weekly for a period of 4 weeks and then monthly for a period of 3 months. The rabbits were bled 7 days after the last dose [19]. The immunoglobulin fractions of the antisera were separated by precipitation with ammonium sulfate and stored at $-70{ }^{\circ} \mathrm{C}$. These antisera reacted with $P$. brasiliensis cell-free fungal extracts and gp43, at titers of $1: 200$ and $1: 100$, respectively, by immunoblotting.

\subsection{Cell culture}

Monolayers of African green monkey Vero cells, obtained from the American Type Culture Collection, were cultured in 199 medium (Sigma, USA) supplemented with 10\% (v/v) fetal calf serum (FCS; Cultilab, Brazil).

\subsection{Immunofluorescence microscopy}

Immunofluorescence microscopy was performed as previously described and adapted [16], using suspensions of yeast forms of $P$. brasiliensis $\left(10^{7}\right.$ cells $\left./ \mathrm{ml}\right)$. Briefly, yeasts were resuspended in phosphate-buffered saline (PBS) $10 \mathrm{mM}, \mathrm{pH}$ 7.4, containing the ECM components at a concentration of $500 \mu \mathrm{g} / \mathrm{ml}$ (fibronectin, laminin, types I and IV collagen) or 
bovine serum albumin (BSA) and incubated for $3 \mathrm{~h}$ at $37{ }^{\circ} \mathrm{C}$. The suspensions were washed and resuspended with specific ECM antibodies (Sigma) diluted 1:10 in PBS, and finally incubated for $1 \mathrm{~h}$ at $37^{\circ} \mathrm{C}$. Suspensions were then washed and resuspended in goat anti-rabbit (1:20 dilution, Sigma) for laminin and fibronectin, and goat anti-mouse IgG FITC conjugate in PBS for types I and IV collagen, for $1 \mathrm{~h}$ at $37^{\circ} \mathrm{C}$. Finally, the suspensions were washed again and examined. Negative controls consisted of yeast suspensions incubated with BSA, anti-ECM protein antibodies and FITC-conjugated antibodies (all replaced with PBS).

\subsection{P. brasiliensis yeast-cell adherence assays}

Assays of ECM protein binding by indirect fluorescence [12]: suspensions of yeast containing about $10^{7}$ cells $/ \mathrm{ml}$ were washed once and resuspended with increasing amounts $(10-500 \mu \mathrm{g} / \mathrm{ml})$ of laminin, fibronectin, types I and IV collagen in $250 \mu \mathrm{l}$ sterile PBS (all ECM proteins obtained from Sigma Chemical, Poole, UK). After $3 \mathrm{~h}$ incubation at $37^{\circ} \mathrm{C}$, the suspensions were washed three times in PBS and incubated for $1 \mathrm{~h}$ at $37{ }^{\circ} \mathrm{C}$ with rabbit anti-laminin and anti-fibronectin or mouse anti-types I and IV collagen (Sigma) diluted 1:100 in PBS plus 1\% BSA. The suspension was washed and resuspended in fluorescein isothiocyanate (FITC)-conjugated goat anti-rabbit immunoglobulin antibody or goat anti-mouse immunoglobulin antibody (1:60 dilution made up in PBS), and incubated for $1 \mathrm{~h}$ at $37^{\circ} \mathrm{C}$. Negative controls consisted of yeast suspensions incubated with BSA, anti-ECM protein antibodies and FITC-conjugated antibodies (all replaced with PBS). The suspensions were washed once more, subsequently fixed in $1 \%$ paraformaldehyde solution in PBS and finally examined by flow cytometry. All flow cytometry analyses were performed on an EPICS XL (Coulter Eletronics, Hialeah, FL, USA) using an air-cooled argon-ion laser tuned at $488 \mathrm{~nm}$ and $115 \mathrm{~mW}$. The flow rate was kept at approximately 10,000 events (cells), and green fluorescence was amplified logarithmically. Ten thousand events were collected as monoparametric histograms of log fluorescence, as well as list mode data files. The data were analyzed by Scatchard GraphPad Prism ${ }^{\circledR}$. Analysis of the data provided the dissociation constants $\left(K_{\mathrm{d}}\right)$.

\subsection{Cell-free fungal extract adherence assays}

ECM proteins, represented by laminin, fibronectin, and types I and IV collagen, were immobilized on 96-well microtiter plates at $10 \mu \mathrm{g} / \mathrm{ml}$. Some assays were performed with $120-$ and $40-\mathrm{kDa}$ fibronectin fragments at $25 \mu \mathrm{g} / \mathrm{ml}$. The plates were incubated for $1 \mathrm{~h}$ at $37{ }^{\circ} \mathrm{C}$ and overnight at $4{ }^{\circ} \mathrm{C}$, washed in PBS-T and blocked with PBS, nonfat dried milk and BSA for $1 \mathrm{~h}$ at $37^{\circ} \mathrm{C}$. Finally, the plates were washed and biotinlabeled cell-free extracts of $P$. brasiliensis (strains 18a and b) were added to each well at $100 \mu \mathrm{g} / \mathrm{ml}$, followed by incubation for $1 \mathrm{~h}$ at $37^{\circ} \mathrm{C}$. The wells were washed three times with PBS-T, followed by incubation with $50 \mu \mathrm{l}$ of peroxidaseconjugated streptavidin (diluted 1:1000 in PBS) for $1 \mathrm{~h}$ at room temperature, and then washed again as described above. Semiquantitative analysis of bound cell-free fungal extracts was conducted by the addition of peroxidase substrate to the wells and determination of the optical density at $492 \mathrm{~nm}$ (OD492) [14]. In all experiments, a conjugate control was used, as well as a negative control without cells. Data shown are relative to the negative control (without cell-free fungal extract). These assays were performed in triplicate, and statistical analyses were conducted by ANOVA ( $F$ test followed by Duncan test).

\section{9. gp43 and synthetic peptide inhibition assays}

Vero cells $\left(1 \times 10^{6}\right.$ cells $\left./ \mathrm{ml}\right)$ were grown in microtiter plates, fixed with paraformaldehyde, washed and blocked with PBS and $10 \% \mathrm{FCS}$ for $1 \mathrm{~h}$ at room temperature and then treated with gp 43 $(10 \mu \mathrm{g} / \mathrm{ml})$ in the presence and absence of individual synthetic peptides $(200 \mu \mathrm{g} / \mathrm{ml})$, as described by Manque et al. [20]. After $1 \mathrm{~h}$ at $37^{\circ} \mathrm{C}$, cells were washed with PBS and incubated with anti-gp43 (1:100) and peroxidase-labeled goat anti-rabbit $\operatorname{IgG}(1: 3000)$ in PBS-FCS. The ELISA protocol was completed as described above. As a negative control, gp43 was omitted and replaced by PBS. The peptide fragments Arg-Gly-Asp-Ser (RGDS), from fibronectin and laminin, and Tyr-Ile-Gly-SerArg (YIGSR) and Cys-Asp-Pro-Gly-Try-Ile-Gly-Ser-Arg- $\mathrm{NH}_{2}$ (CDPGYIGSR-NH $\mathrm{N}_{2}$ ) from laminin (Sigma) were used, as well as synthetic fragments that represent specific sequences of gp43: Asn-Leu-Gly-Arg-Asp-Ala-Lys-Arg-His-Leu (PEP $1=$ NLGRDAKRHL), Ser-Ala-Gln-Gln-Lys-Lys-Asp-ThrLeu-Arg-Tys-Ile (PEP $2=$ SAQQKKDTLRYI), Ile-Thr-GluAsp-Asp-Phe-Lys-Asn-Ile-Ala (PEP $3=$ ITEDDF-KNIA) and Lys-Gln-Thr-Leu-Ile-Ala-Ile-His-Thr-Leu-Ala-Ile-ArgTyr-Ala-Asn (PEP $4=$ KQTLRTAHTLAIRYAN) (Genosys Biotechnologies).

\subsection{Molecular modeling}

The objective of molecular modeling is to evaluate the presence of these peptides on molecular surface and solvent accessibility to predict protein-protein interaction permission. The sequence of the mature immunodominant antigen gp43 ( $\beta$ glucanase-like protein from $P$. brasiliensis), comprising 381 residues, was extracted from the sequence deposited in TrEMBL Protein Databank under accession number Q01575. ExoB-(1,3)-glucanase from C. albicans (PDB ID 1EQP, $1.90 \AA$ resolution; 1 cz1a, $1.85 \AA$ resolution and 1eqc, $1.85 \AA$ resolution) and Exo-B-(1,3)-glucanase from Saccharomyces cerevisiae (PDB ID 1H4P, $1.75 \AA$ resolution) were used in the modeling procedure in Swiss model, being submitted for a first-approach model, and visualized by SwissPDB Viewer v3.7. The PROCHECK suite of programs was used for model validation [21].

\subsection{Immunoblotting}

Adhesins involved in $P$. brasiliensis-ECM interactions were characterized by immunoblotting. Proteins of the fungal extract from $P$. brasiliensis $18 \mathrm{~b}$ isolate were separated by 
SDS-PAGE and transferred to a nitrocellulose membrane. Immunoblotting analysis was carried out as previously described [12]. Briefly, membrane strips were prepared, blocked with $1 \%$ BSA in PBS for $4 \mathrm{~h}$, and then probed with laminin (10, 20 and $30 \mu \mathrm{g} / \mathrm{ml})$, fibronectin (10 and $20 \mu \mathrm{g} / \mathrm{ml}$ ) and type I collagen $(10 \mu \mathrm{g} / \mathrm{ml})$ in PBS-T-BSA for $90 \mathrm{~min}$ at room temperature. The membrane strips were washed and then incubated overnight with rabbit anti-laminin, anti-fibronectin and anti-type I collagen antibodies (1:100) in PBS-T-BSA. After further washing, they were incubated with a goat anti-rabbit peroxidase conjugate (Sigma, St. Louis. MO, USA) diluted 1:1000 in PBS-T-BSA and washed again. Peroxidase was visualized with $0.05 \%$ diaminobenzidine in Tris- $\mathrm{HCl}$ buffer (pH 7.4) and $\mathrm{H}_{2} \mathrm{O}_{2}(0.1 \%)$ as substrate. The specificity of the reaction was assessed by omitting the ECM proteins or by using a nonspecific immune serum instead of the ECM antisera. The positive control was developed from paracoccidioidomycosis patient serum (1:40).

\subsection{Statistical analysis}

Analysis of variance (ANOVA), Fisher's exact probability test (SAS System) and an unpaired $t$ test were used to compare the binding capabilities of the cell-free fungal extracts and ECM proteins as well as to determine differences among the treatments, samples and proteins, $p<0.05$ being considered significant.

\section{Results}

\subsection{Binding of ECM components to P. brasiliensis yeast cells}

The surface of $P$. brasiliensis yeast cells (Pb18b) demonstrated strong immunofluorescent labeling when incubated with laminin, fibronectin and types I and IV collagen, indicating clear interactions between the yeast cells and these ECM components (Fig. 1). Laminin and fibronectin fluorescence was scattered, granular and diffuse all over the whole fungus cell wall (Fig. 1A and B). Type I collagen expressed a dominant linear pattern on the surface, with some granular deposits (Fig. 1C). The type IV collagen fluorescence tended to be more linearly arranged, with no clear spatial localization (Fig. 1D). No reactivity was evident when the cells were incubated in the absence of ECM components (data not shown), demonstrating that the immunofluorescence depended on prior interaction of the cells with ECM proteins and the appropriate recognition. None of the other negative controls demonstrated any fluorescent activity.

\subsection{Adherence of $\mathrm{Pb}$ yeast cells to ECM components}

The ability of $P$. brasiliensis ( $\mathrm{Pb} 18 \mathrm{~b}$ ) yeast cells to adhere to the ECM components (laminin, fibronectin, types I and IV collagen) is illustrated in Fig. 2. Several yeast cell concentrations were tested, and $10^{7}$ cells $/ \mathrm{ml}$ gave a linear and more inoculum-dependent correlation in the flow cytometry assay
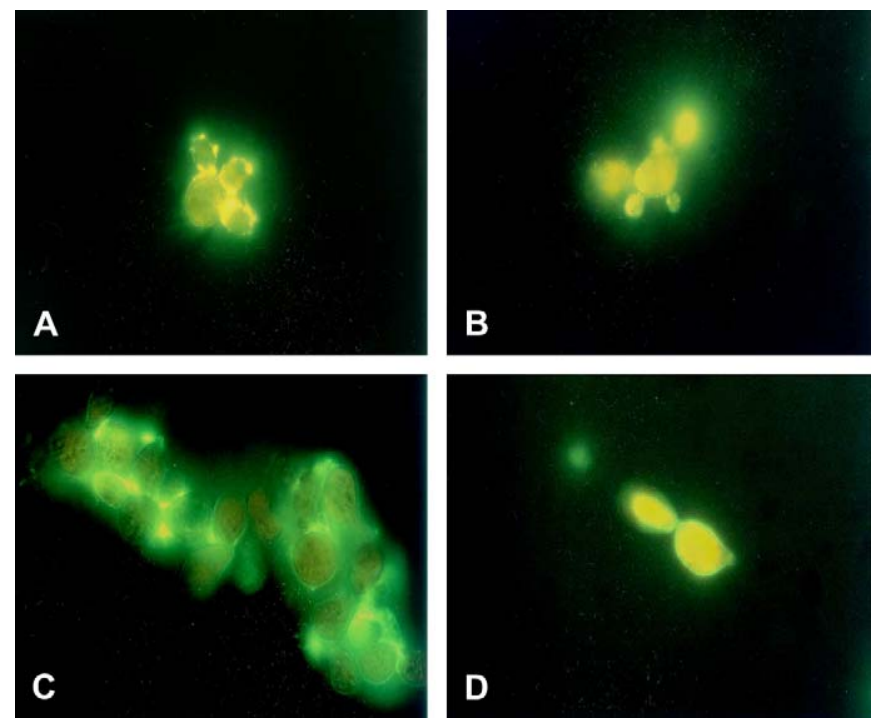

Fig. 1. Binding of laminin (A), fibronectin (B), type I collagen (C) and type IV collagen (D) on the yeast cell surface of $P$. brasiliensis sample $18 \mathrm{~b}$ detected by indirect immunofluorescence assay. Yeast cells were incubated with ECM proteins, then with specific ECM antibodies, and finally with fluorescein isothiocyanate (FITC)-conjugated anti-rabbit immunoglobulin to laminin and fibronectin and anti-mouse immunoglobulin to types I and IV collagen.

(data not shown). When yeast cells were incubated with the various concentrations of ECM proteins $(10-500 \mu \mathrm{g} / \mathrm{ml})$, it was found that the ligand bound to the cells in a dosedependent manner. The intensity of the fluorescence detected at the surface of yeast cells increased with the concentration of the ligand in solution, attesting to the saturability of binding. The cells adhered to types I and IV collagen and laminin immobilized at concentrations ranging from 10 to $100 \mu \mathrm{g} / \mathrm{ml}$. In the fibronectin assay, a higher concentration (10-500 $\mu \mathrm{g} / \mathrm{ml})$ was needed to obtain similar behavior. Analysis of these data provided the dissociation constants $\left(K_{\mathrm{d}}\right)$. The fibronectin showed the highest value $\left(K_{\mathrm{d}}=19.48\right)$, suggesting a weak attachment of the fungal cells to this protein (Fig. 2A).

\subsection{Adherence of cell-free components of $\mathrm{Pb}$ to ECM}

This fungal extract preparation corresponds to the most superficial part of the fungal cell and is probably the one that enters most directly in contact with the cells of the host. The ability of the two fungal extracts to bind ECM proteins is demonstrated in Fig. 3. By applying ANOVA ( $F$ test followed by Duncan test), different interactions were observed between the two fungal extracts and ECM components. As shown in Fig. 3, Pb18b extract bound more intensely to the ECM than did the Pb18a extract $(p<0.005)$. Laminin was most reactive, followed by type I collagen, fibronectin and type IV collagen, in relation to $\mathrm{Pb} 18 \mathrm{~b}$ extract. In contrast, $\mathrm{Pb} 18 \mathrm{a}$ extract exhibited a different pattern of binding strength (in descending order: laminin, type I collagen, type IV collagen and fibronectin). The interaction of both extracts with laminin was 
A

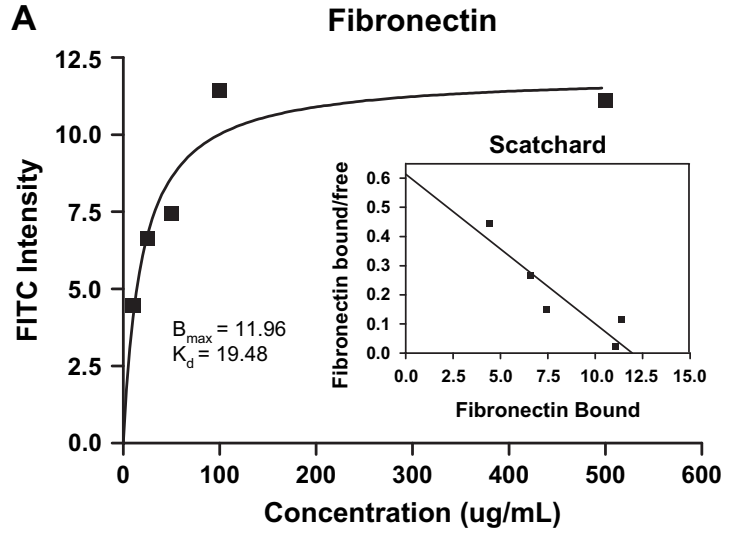

C

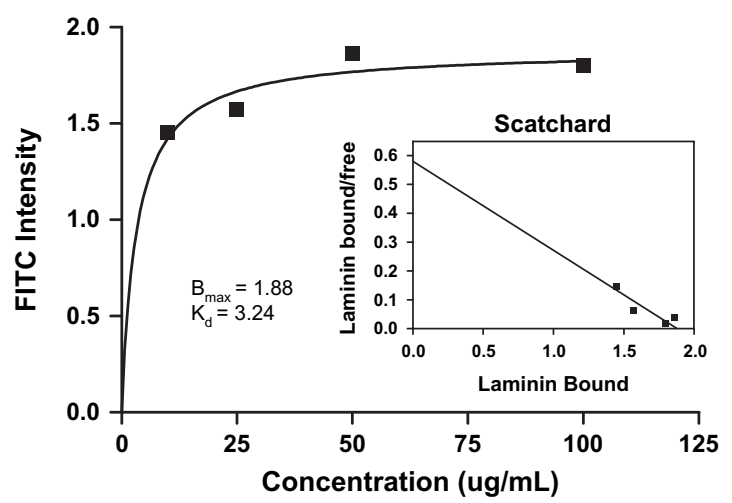

B

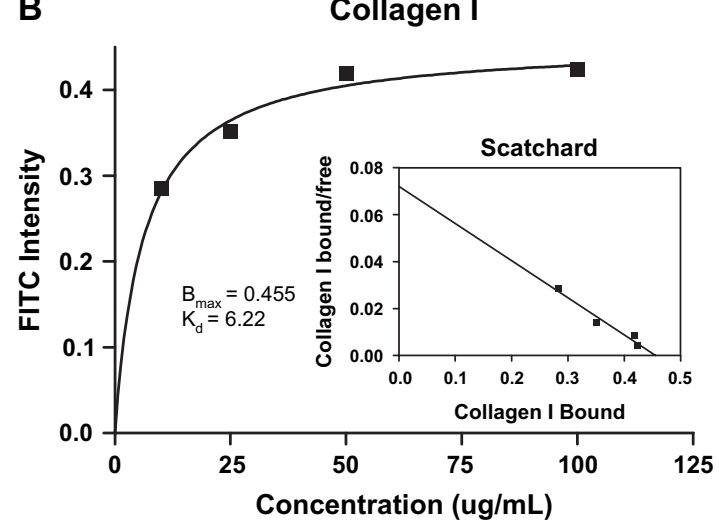

D

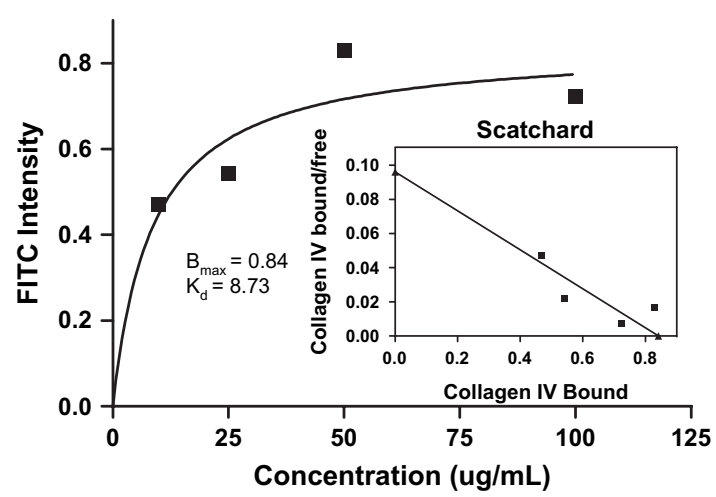

Fig. 2. P. brasiliensis (Pb18b) adhesion $\left(10^{7}\right.$ cells $\left./ \mathrm{ml}\right)$ to ECM proteins $(10-500 \mu \mathrm{g} / \mathrm{ml})$. A. Fibronectin; B. Collagen I; C. Laminin and D. Collagen IV. The interaction was assayed by indirect immunofluorescence and analyzed by flow cytometry. Ten thousand events were collected as monoparametric histograms of log fluorescence, as well as list mode data files. The data were analyzed by Scatchard Graphpad Prism. Analysis of the data provided the dissociation constants $\left(K_{\mathrm{d}}\right)$.

significantly different from those with all other ECM components $(p<0.05)$, and remarkably different interactions were observed between fibronectin and the two different fungal extracts $(p \leq 0.0005)$.

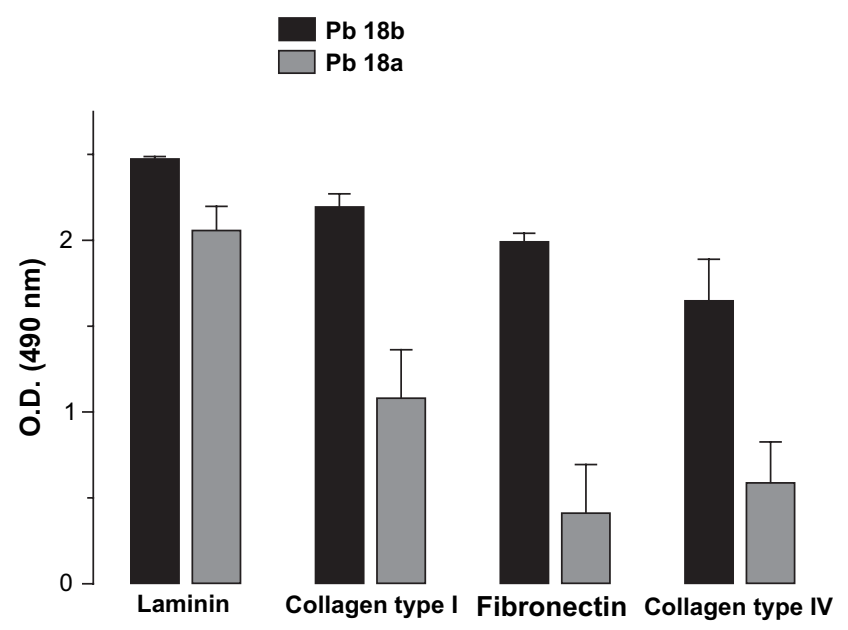

Fig. 3. P. brasiliensis $18 \mathrm{a}$ and $18 \mathrm{~b}$ biotin-labeled cell-free fungal extract $(100 \mu \mathrm{g} / \mathrm{ml})$ interaction with immobilized types I and IV collagen, fibronectin and laminin $(10 \mu \mathrm{g} / \mathrm{ml})$. The interaction was revealed by ELISA with peroxidase-conjugated streptavidin. The results were expressed in absorbance units and correspond to mean values $\pm \mathrm{SD}$ of triplicate experiments.

\subsection{Fibronectin adherence to $\mathrm{P}$. brasiliensis cell-free fungal extracts}

Since many fibronectin-binding proteins are known to interact with specific regions of fibronectin, additional experiments were undertaken with two purified fibronectin proteolytic fragments, one comprising the RGD cell-binding domain $(120 \mathrm{kDa})$, and the other the heparin-binding domain (40 kDa). Cell-free fungal extracts of the two P. brasiliensis isolates (18b and a) adhered to fibronectin in different ways. Conversely to $\mathrm{Pb} 18 \mathrm{a}$ extract, $\mathrm{Pb} 18 \mathrm{~b}$ extract exhibited stronger interaction with the $120-\mathrm{kDa}$ fragment than with the $40-\mathrm{kDa}$ fragment $(p<0.05)$, while $\mathrm{Pb} 18 \mathrm{a}$ extract reacted more with the 40 - than the $120-\mathrm{kDa}$ fragment. Binding of the extracts to the fragments was only observed when coating was performed with solutions of at least $25 \mu \mathrm{g} / \mathrm{ml}$ of the fragments bound to the plate, whereas $10 \mu \mathrm{g} / \mathrm{ml}$ intact fibronectin promoted adhesion (Fig. 4).

\subsection{Immunoblotting assay}

The cell-free extract of $\mathrm{Pb} 18 \mathrm{~b}$ contained a complex array of polypeptide chains ranging from 14 to $106 \mathrm{kDa}$. Laminin binding was observed with four major components whose molecular masses were approximately 30, 34, 38, 43 and $68 \mathrm{kDa}$ : fibronectin 


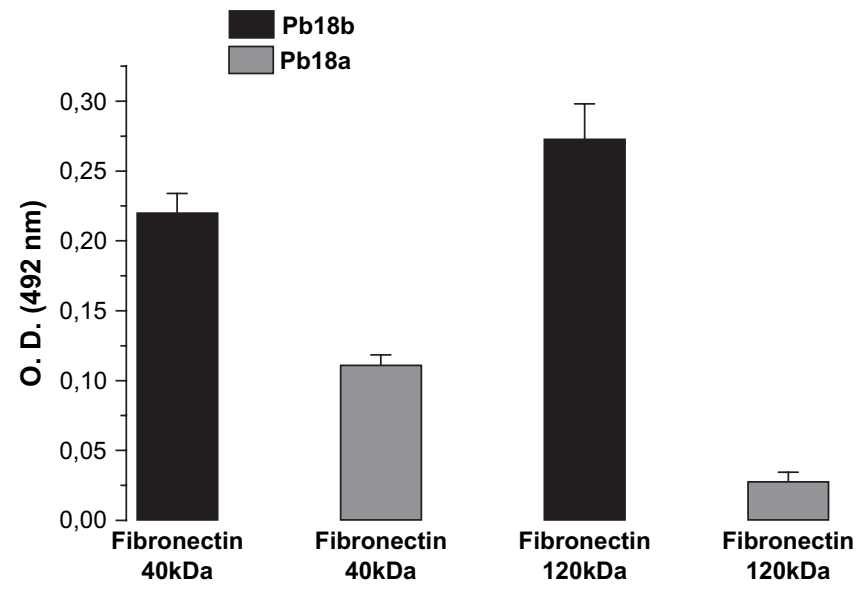

Fig. 4. P. brasiliensis biotin-labeled cell-free fungal extract $(100 \mu \mathrm{g} / \mathrm{ml})$ interaction with fibronectin and the immobilized fragments at $25 \mu \mathrm{g} / \mathrm{ml}$. The interaction was revealed by ELISA with peroxidase-conjugated streptavidin. The results were expressed in absorbance units and correspond to mean values \pm SD of triplicate experiments.

with five components, of $15,28,34$ and $43 \mathrm{kDa}$ and type I collagen with two components, of 47 and $80 \mathrm{kDa}$ (data not show). gp 43 was recognized by both laminin and fibronectin. Controls performed by omission of the ECM proteins were negative, attesting the specificity of these reactions.

\subsection{Peptide inhibition}

To further characterize the cell-binding site of gp43, we performed binding-inhibition experiments by incubating Vero cells with gp43 protein in the presence of individual gp43 peptides. Peptide 1 (NLGRDAKRHL) had the strongest inhibitory effect on the adhesion of gp43 to Vero cells (57\%) $(p<0.05)$, followed by the peptides PEP 2 (SAQ QKKDTLRYI), PEP 3 (ITEDDFKNIA) and PEP 4 (KQTLRTAHTLAIRYAN) (Fig. 5A), with 29.2\%, 27.0\% and 24.5\% inhibition, respectively. Besides being present in ECM, fibronectin and laminin are associated with epithelial cells. Accordingly, we asked whether these ECM components might serve as receptors in the interactions between gp43 and cultured epithelial cells. In order to probe the molecular mechanisms involved in gp43 adherence, competitive binding was performed with synthetic peptides corresponding to the adhesive recognition sequences of laminin and fibronectin. Synthetic peptides YIGSR and CDPGYIGSR-NH2, from laminin, respectively, inhibited by $42.5 \%(p<0.0001)$ and $51.5 \%(p<0.0001)$ the binding of gp43 to Vero cells. On the other hand, RGDS peptide showed an inhibitory effect of $43.5 \%(p<0.0001)$ (Fig. 5B).

\subsection{Molecular modeling}

The gp43 was modeled by computer in order to locate the position of peptide 1 in the protein structure. The structure of gp43 resembled fungal beta glucanases (Fig. 6E). The molecular model of gp43 was obtained with 381 aas, started in valine 32 and finished in arginine 416 . Valine 32 until Q 35 is located in the leader peptide region [22]. The model shows the same number of $\alpha$-helices and $\beta$-strands as the homologous protein. Approximately $90 \%$ of the residues were plotted in the most favored regions (Fig. 6A-C) of the Ramachandran plot. The region corresponding to PEP 1 was found on the surface of the protein and showed high solvent accessibility (Fig. 6D). Fig. 6A is the gp43 model demonstrating secondary structures. Fig. $6 \mathrm{~B}-\mathrm{D}$ shows the PEP 1 on the surface of the protein and accessible to protein interaction with ECM. This model was representative of the structure of the protein, and it was constructed using protein homologues (Fig. 6E), which were crystallized. In fibronectin, the RGD motif was present on the surface of the molecule, and the secondary structure was a loop [23,24]. PEP 1 was a loop, and it was present on surface, as observed in the RGD motif. Consequently, the PEP 1 showed characteristics important for protein-protein interaction, as observed in the RGD motif (Fig. 6F).

\section{Discussion}

Adhesion of microorganisms to host cells and tissues represents a critical step in the process of infection $[13,15,16]$. We previously demonstrated that $P$. brasiliensis was capable of adhering to and invading epithelial cells. By comparing several independent isolates of $P$. brasiliensis, it was also observed
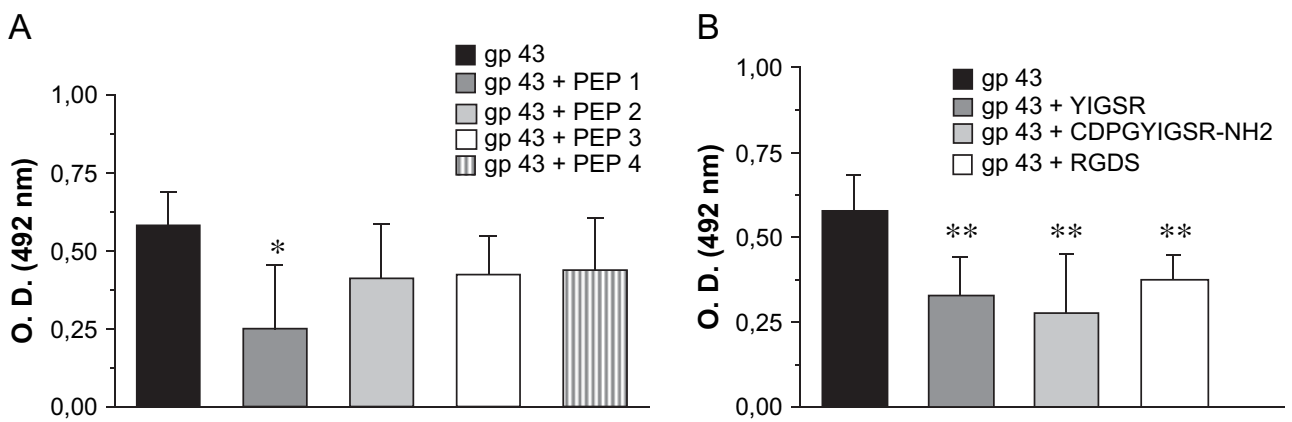

Fig. 5. Competitive assay with gp43 and peptides during the interaction with Vero cells. (A) Vero cells were incubated with gp 43 (10 $\mu \mathrm{g} / \mathrm{ml})$, gp 43 peptides $(200 \mu \mathrm{g} / \mathrm{ml})$ and anti-gp43 antiserum (1:100). (B) cells incubated with gp43 $(10 \mu \mathrm{g} / \mathrm{ml})$; gp43 $(10 \mu \mathrm{g} / \mathrm{ml})$ and the synthetic peptides of laminin and fibronectin, respectively, CDPGYIGSR-NH2, YIGSR and RGDS, and anti-gp43 antiserum (1:100). The interaction was visualized by ELISA. The results are expressed in absorbance units and correspond to mean values \pm SD of triplicate experiments. $(*)=p<0.05$ and $(* *)=p<0.0001$. 

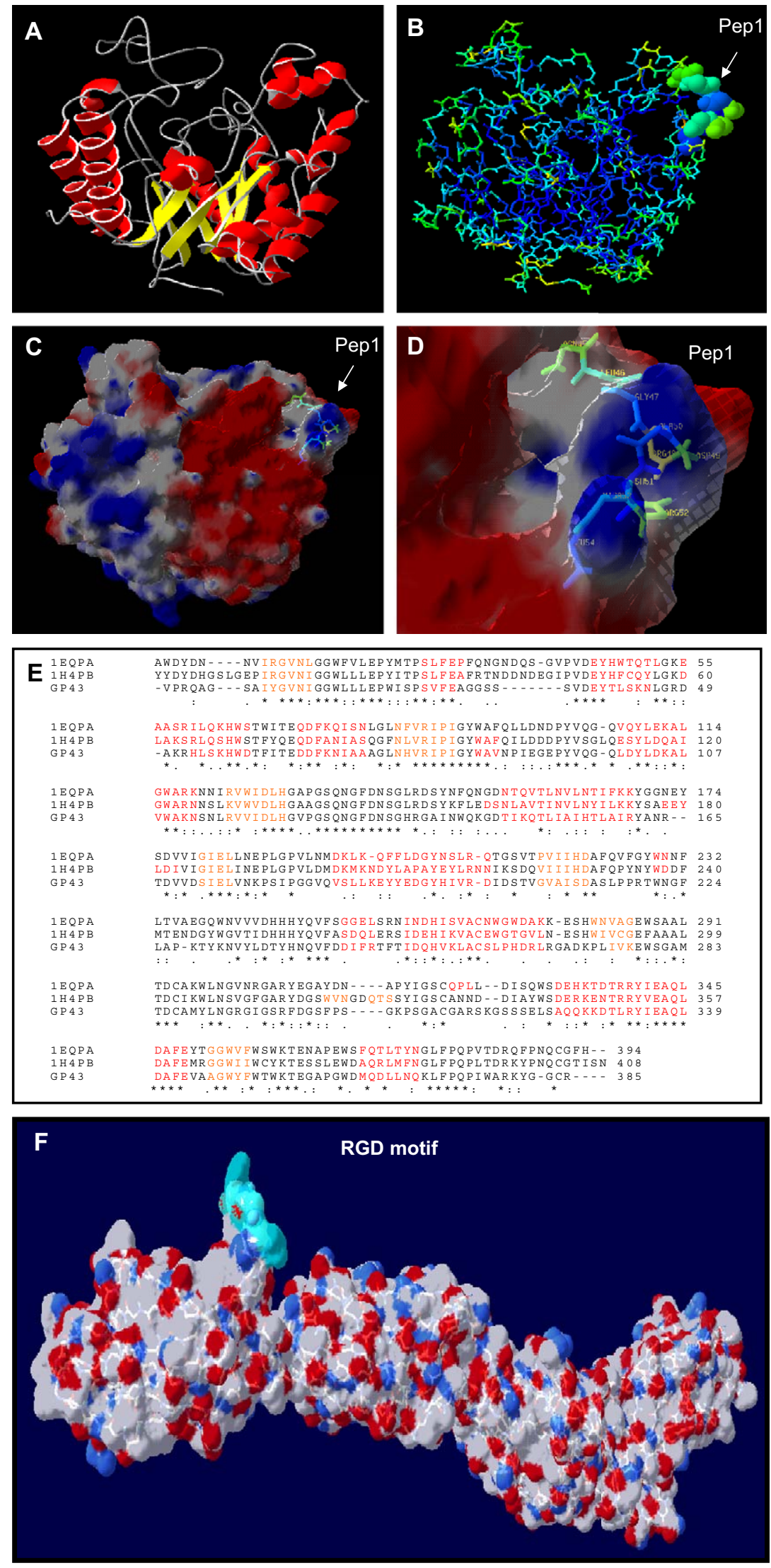

Fig. 6. Panel A: gp43 molecular model ribbon representation colored for secondary structure (red, $\alpha$ helices; yellow, $\beta$ strands; grey, loops. Panel B: gp 43 structure colored for solvent accessibility. Panel C: The surface of gp43 was mapped. The surface was made transparent to allow the perception of the internal protein architecture and colored according to the Coulombic electrostatic potential: red, negative; grey, neutral; and blue, positive. Panel D: Top view of PEP 1 on gp43 structure. The secondary structure, solvent accessibility and molecular surfaces were calculated in SwissPDB Viewer v3.7. Panel E: Multiple sequence alignment of glucanases from $C$. albicans, S. cerevisiae and P. brasiliensis used in the construction of the model. Secondary elements are represented in orange ( $\beta$ strands) and in red ( $\alpha$ helices). Panel F: Molecular model of fibronectin indicating the surface position of the RGD motif. 
that strains that were most virulent in animals exhibited enhanced adhesion in vitro. In particular, we found that strain 18 , described as the most virulent in animals, had the strongest adhesion [5]. $P$. brasiliensis strain 18 lost the capacity to adhere after many consecutive cycles of subculturing over long periods [8], but reestablished it after infecting animals or animal cell cultures. In the last three decades, several studies have demonstrated that some infectious agents produce molecules that bind to components of the ECM. In the present work, the interactions of two isolates, $\mathrm{Pb} 18 \mathrm{a}$ and $\mathrm{b}$ were investigated with Vero cells and ECM proteins. Fungal cells were bound to immobilize ECM proteins, and the immunofluorescence labeling clearly demonstrated the presence of laminin, fibronectin and types I and IV collagen-binding sites on the surface of $P$. brasiliensis yeast cells.

ECM proteins were recognized by both strains in ELISA assay, although they exhibited different adhesion patterns when the tests were performed with $\mathrm{Pb} 18 \mathrm{a}$ and $\mathrm{b}$ extracts. Probably, distinct recognition components enhance the differences in adhesion and virulence between the two isolates. As already mentioned, $P$. brasiliensis strains are not homogeneous in their behavior, a fact noted by several authors $[4,5,25]$. The reisolated sample (18b) demonstrated a higher capacity to adhere to ECM proteins than the subcultured one (18a). Singer-Vermes et al. [25] showed that the higher virulence of strain 18 compared to other strains was probably related to antigenic differences between strains. Probably, adhesion is one important factor among several that promotes the development of this infectious process.

Laminin, the main component of the basement membranes [26] seems to be important in $\mathrm{Pb} 18$ adhesion. Attachment to the ECM component laminin might be responsible for triggering the initiation of $P$. brasiliensis infection, since tissue injury that damages the epithelial layer would expose the laminin-rich basement membrane. In addition, $P$. brasiliensis attachment to laminin may play a role in fungus dissemination and tissue invasion [7]. However, Andre et al. [27] showed that treatment with laminin did not enhance $P$. brasiliensis pathogenicity in a pulmonary model of infection, even when low infecting doses of the virulent yeast $(\mathrm{Pb} 18)$ or a low-virulence isolate $(\mathrm{Pb} 265)$ was used. Here it was confirmed that $P$. brasiliensis uses this protein in the process of adhesion to the host cells, as previously described in several studies [7-10].

The present results also indicate that $P$. brasiliensis interacts with human fibronectin. In fact, both $P$. brasiliensis $18 \mathrm{a}$ and $18 \mathrm{~b}$ fungal extracts were adhered to the fibronectin fragments, although they presented distinct recognition patterns. Fungal extract $18 \mathrm{~b}$ interacted more strongly with whole fibronectin and more with the $120-\mathrm{kDa}$ fragment than with the $40 \mathrm{kDa}$ one, in contrast to $\mathrm{Pb} 18 \mathrm{a}$ fungal extract, which interacted more with the $40-\mathrm{kDa}$ fragment than with the $120-\mathrm{kDa}$ fragment. These results suggest that $P$. brasiliensis strain 18 links differently to the two fibronectin fragments, and more intensely to the entire molecule. Likewise, Penn and Klotz [28] demonstrated that $C$. albicans interacted more strongly with the 120-kDa fragment, which contains the cell-linking sequence (RGD). The existence of multiple binding to fibronectin fragments may be a characteristic of pathogens interacting with proteins of the extracellular matrix. On the other hand, A. fumigatus conidia preferentially bound to the nonglycosylated 40-kDa fragment, which contains the glycosaminoglycan (GAG)-binding domain [29]. This difference could be explained by the distinct molecules, which participate in the pathogen interaction among ECM components. Binding to the RGD sequence appears to guarantee a stronger molecular interaction than carbohydrate linkages, which are commonly weaker.

Collagen is the main constituent of the ECM and represents the main target for the binding of many species of microorganisms [3]. The recognition of type I collagen was notable, and these data are consistent with those of Kerr et al. [30], where the synthesis of extracellular matrix after injury started with the deposition of the fibrin-like material. Such comparative histopathological analysis emphasizes the involvement of collagen in the pathogenesis of $P$. brasiliensis [4]. In addition, Klotz [31] also showed that $C$. albicans bound to immobilized types I and IV collagen.

Analysis by SDS-PAGE and ligand blotting with ECM components identified, besides gp43, other fungal extract components that bind laminin and fibronectin. On the other hand, gp43 had significant homologies to the fibronectin molecule (data not shown), which may reinforce this interaction. Type I collagen was recognized by $47-$ and $80-\mathrm{kDa}$ proteins. Thus, we can speculate that laminin and fibronectin may mediate the adhesion of gp43 to Vero cells. Multifunctional adhesins have been described at the surface of numerous pathogens [4,32], as observed for us.

In recent years, several molecules with receptor-like characteristics have been described in pathogenic fungi [32]. Most of these microbial molecules are glycoproteins present in the cell wall and are known as adhesins, displaying properties analogous to integrins. They generally recognize RGDcontaining peptides in various tissues [3]. Competitive assays with RGDS, which is part of the fibronectin and laminin molecules, reduced by approximately $43.5 \%$ the binding of gp43 to the Vero cells. On the other hand, CDPGYIGSR-NH2 and YIGSR derived from the laminin reduced the binding by $51.5 \%$ and $42.5 \%$, respectively. RGD peptide was shown to be a competitive ligand to other fungi [33]. On the basis of our data one can speculate that the proteins laminin and fibronectin mediate the adhesion of gp43 to the Vero cells; certainly, we know that $P$. brasiliensis cell-free fungal extracts can bind several ECM proteins, including collagen, fibronectin and laminin.

Four peptides have been delineated within the sequence of gp43, three of which have hydrophobic, and one, hydrophilic structure. Peptide 1 (NLGRDAKRHL), corresponding to residues 76-85, competed with gp43 and significantly inhibited the adhesion of $P$. brasiliensis to the Vero cells by approximately $60 \%$. This gp43 segment contains several positively charged amino acids. Apparently, the greater contribution that PEP 1 makes to the inhibition of gp43 binding to the cells may be correlated with these positively charged residues, in accordance with a previous study in Trypanosoma cruzi, 
whose binding of gp82 to HeLa cells involved strong adhesion by several positively charged amino acids [20]. Furthermore, the external localization of this peptide on the native molecule suggests its importance in the ECM interaction, indicating that this site could participate in protein-protein interaction in the native protein and can be responsible for adhesion to ECM proteins. The most interesting evidence in this model is that the region corresponding to PEP 1 forms a loop and in solution adopts the same conformation. In fibronectin, for example, the RGD motif is present on the molecule's surface and the secondary structure is a loop [23,24]. Consequently, the PEP 1 shows characteristics important for protein-protein interaction, as observed with the RGD motif. Besides, this peptide has a GRD sequence, that is a truncated version of the RGD motif. This structure could have an influence on the adhesion of fungi in vitro. In conclusion, this study has provided new molecular details of the interaction between $P$. brasiliensis and ECM components, using in vitro cellular models and adherence assays.

\section{Acknowledgements}

This investigation was financially supported by the Brazilian organizations, FAPESP, Conselho Nacional de Desenvolvimento Científico e Tecnológico (CNPq) and PADC-FCF-UNESP.

\section{References}

[1] M. Franco, C.S. Lacaz, A. Restrepo-Moreno, G. Del Negro (Eds.), Paracoccidioidomycosis, CRC Press, Boca Raton, 1994.

[2] S.E. Dunsmore, D.E. Rannels, Extracellular matrix biology in the lung, Am. J. Physiol. 270 (1996) 3-27.

[3] J.M. Patti, B.L. Allen, M.J. Mc Gavin, M. Hook, MSCRAMM-mediated adherence of microorganisms to host tissues, Annu. Rev. Microbiol. 48 (1994) 585-617.

[4] M.J.S. Mendes-Giannini, M.L. Taylor, J.B. Bouchara, E. Burger, V.L.G. Calich, E.D. Escalante, S.A. Hanna, H.L. Lenzi, M.P. Machado, M. Miyaji, J.L. Monteiro da Silva, E.M. Mota, A. Restrepo, S. Restrepo, G. Tronchin, L.R. Vincenzi, C.F. Xidieh, E. Zenteno, Pathogenesis II: fungal responses to host responses: interaction of host cells with fungi, Med. Mycol. 38 (2000) 113-123.

[5] S.A. Hanna, J.L. Monteiro da Silva, M.J.S. Mendes-Giannini, Adherence and intracellular parasitism of Paracoccidioides brasiliensis in Vero cells, Microbes Infect. 2 (2000) 877-884.

[6] E. Brummer, A. Restrepo, L.H. Hanson, D.A. Stevens, Virulence of Paracoccidioides brasiliensis: the influence of in vitro passage and storage, Mycopathologia 109 (1990) 13-18.

[7] A.P. Vicentini, J.L. Gesztesi, M.F. Franco, W. Souza, J.Z. Moraes, L.R. Travassos, J.D. Lopes, Binding of Paracoccidioides brasiliensis to laminin through surface glycoprotein gp43 leads to enhancement of fungal pathogenesis, Infect. Immun. 62 (1994) 1465-1469.

[8] P.F. Andreotti, J.L. Monteiro da Silva, A.M. Bailão, C.M. Soares, G. Benard, C.P. Soares, M.J.S. Mendes-Giannini, Isolation and partial characterization of a $30 \mathrm{kDa}$ adhesin from Paracoccidioides brasiliensis, Microbes Infect. 7 (2005) 875-881.

[9] A. Gonzalez, B.L. Gomez, S. Diez, O. Hernandez, A. Restrepo, A.J. Hamilton, L.E. Cano, Purification and partial characterization of a Paracoccidioides brasiliensis protein with capacity to bind to extracellular matrix proteins, Infect. Immun. 73 (2005) 2486-2495.

[10] M.S. Barbosa, S.N. Báo, P.F. Andreotti, F.P. de Faria, M.S.S. Felipe, L.S. Feitosa, M.J.S. Mendes-Giannini, C.M.A. Soares, Glyceraldehyde- 3-phosphate dehydrogenase of Paracoccidioides brasiliensis is a cell surface protein involved in fungal adhesion to extracellular matrix proteins and interaction with cells, Infect. Immun. 74 (2005) 382-389.

[11] J.P. Bouchara, G. Tronchin, V. Annaix, R. Robert, J.M. Senet, Laminin receptors on Candida albicans germ tubes, Infect. Immun. 58 (1990) $48-54$.

[12] J.P. Bouchara, M. Sanchez, K. Esnault, G. Tronchin, Interactions between Aspergillus fumigatus and host matrix proteins, Contrib. Microbiol. 2 (1999) 167-181.

[13] O.C. Lima, C.C. Figueredo, V. Morandi, L.M. Lopes-Bezerra, Adhesion of human pathogen Sporothrix schencckii to several extracellular matrix proteins, Braz. J. Med. Biol. Res. 32 (1999) 651-657.

[14] C.Y. Hung, J.J. Yu, K.R. Seshan, U. Reichard, G.T. Cole, A parasitic phase-specific adhesin of Coccidioides immitis contributes to the virulence of this respiratory fungal pathogen, Infect. Immun. 70 (2002) 3443-3456.

[15] J.P. Mc Mahon, J. Wheat, M.E. Sobel, R. Pasula, J.F. Downing, W.J. Martin, Murine laminin binds to Histoplasma capsulatum. A possible mechanism of dissemination, J. Clin. Invest. 96 (1995) 1010-1017.

[16] A.J. Hamilton, 1. Jeavons, S. Youngchim, N. Vanittanaton, Recognition of fibronectin by Penicillium marneffei conidia via sialic acid-dependent process and its relationship to the interaction between conidia and laminin, Infect. Immun. 67 (1999) 5200-5205

[17] C.S. Lacaz, E. Porto, J.E.C. Martins (Eds.), Micologia médica: fungos, actinomicetos e algas de interesse médico, Sarvier, São Paulo, 1991.

[18] M.H.S. Blotta, Z.P. Camargo, Immunological response to cell-free antigens of Paracoccidioides brasiliensis: relationship with clinical forms, J. Clin. Microbiol. 31 (1993) 671-676.

[19] G. Benard, M.J.S. Mendes-Giannini, M. Juvenale, E.T. Miranda, A.J.S. Duarte, Immunosuppression in paracoccidioidomycosis: $\mathrm{T}$ cell hyporesponsiveness to two Paracoccidioides brasiliensis glycoproteins that elicit strong humoral immune response, J. Infect. Dis. 175 (1997) $1263-1267$.

[20] P.M. Manque, D. Eichinger, M.A. Juliano, L. Juliano, J.E. Araya, N. Yoshida, Characterization of the cell adhesion site of Trypanosoma cruzi metacyclic stage surface glycoprotein gp82, Infect. Immun. 68 (2000) 478-484.

[21] F.P. Silva Jr., F. Ribeiro, N. Katz, S. Giovanni-De-Simone, Exploring the subsite specificity of Schistosoma mansoni aspartyl hemoglobinase through comparative molecular modeling, FEBS Lett. 514 (2002) 141-148.

[22] P.S. Cisalpino, R. Puccia, L.M. Yamauchi, M.I.N. Cano, J.F. Silveira, L.R. Travassos, Cloning, characterization, and epitope expression of the major diagnostic antigen of Paracoccidioides brasiliensis, J. Biol. Chem. 271 (1996) 4553-4560.

[23] A. Sharma, J.A. Askari, M.J. Humphries, E.Y. Jones, D.I. Stuart, Crystal structure of a heparin- and integrin-binding segment of human fibronectin, EMBO J. 18 (1999) 1468-1479.

[24] D.J. Leahy, I. Aukhil, H.P. Erickson, A crystal structure of a four-domain segment of human fibronectin encompassing the RGD loop and synergy region, Cell 84 (1996) 155.

[25] L.M. Singer-Vermes, E. Burger, M.J. Franco, M. Moscardi Bachi, M.J.S. Mendes-Giannini, V.L.G. Calich, Evaluation of the pathogenicity and immunogenicity of seven Paracoccidioides brasiliensis isolates in susceptible inbred mice, J. Med. Vet. Mycol. 27 (1989) 71-82.

[26] R. Timpl, H. Rodhe, R.P. Gehron, S.I. Rennard, J.M. Foidart, G.R. Martin, Laminin a glycoprotein from basement membranes, J. Biol. Chem. 254 (1979) 9933-9937.

[27] D.C. Andre, J.D. Lopes, M.F. Franco, C.A.C. Vaz, V.L.G. Calich, Binding of laminin to Paracoccidioides brasiliensis induces a less severe pulmonary paracoccidioidomycosis caused by virulent and low-virulence isolates, Microbes Infect. 6 (2004) 549-558.

[28] C. Penn, S.A. Klotz, Binding of plasma fibronectin to Candida albicans occurs through the cell binding domain, Microb. Pathog. 17 (1994) 387-393.

[29] J.A. Wasylnka, M.M. Moore, Adhesion of Aspergillus species to extracellular matrix proteins: evidence for involvement of negatively charged carbohydrates on the conidial surface, Infect. Immun. 68 (2000) 33773384. 
[30] I.B. Kerr, J.R. Araripe, P.C. Oliverira, H.L. Lenzi, Paracoccidioidomycosis: a sequential histopathologic study of lesions in experimentallyinfected rats, Rev. Inst. Med. Trop. 5 (1988) 336-350.

[31] S.A. Klotz, Adherence of Candida albicans to components of the subendothelial extracellular matrix, FEMS Microbiol. Lett. 68 (1990) 249-254.
[32] M.J. Mendes-Giannini, C.P. Soares, J.L. Da Silva, P.F. Andreotti, Interaction of pathogenic fungi with host cells: molecular and cellular approaches, FEMS Immunol. Med. Microbiol. 45 (2005) 383-394.

[33] I.M. Bromley, K. Donaldson, Binding of Aspergillus fumigatus spores to lung epithelial cells and basement membrane proteins: relevance to the asthmatic lung, Thorax 51 (1996) 1203-1209. 